\title{
Outcrossing rates of individual Mimulus ringens genets are correlated with anther-stigma separation
}

\author{
JEFFREY D. KARRON*, ROSELLA T. JACKSON, NINA N. THUMSER \\ \& STEPHANIE L. SCHLICHT \\ Department of Biological Sciences, PO Box 413, University of Wisconsin-Milwaukee, Milwaukee, WI 53201, U.S.A.
}

\begin{abstract}
Anther-stigma separation (herkogamy) is highly variable within populations of Mimulus ringens, a bumblebee-pollinated perennial herb with a mixed-mating system. The relationship between this floral trait and individual outcrossing rates was studied in two experimental populations composed of genets with unique multilocus combinations of homozygous genotypes. This facilitated determination of individual outcrossing rates through unambiguous assignment of paternity to all 1560 sampled progeny. In each population there was significant heterogeneity among maternal families in frequencies of self and outcross progeny. Individual outcrossing rates were positively correlated with anther-stigma separation.
\end{abstract}

Keywords: herkogamy, mating system, monkeyflower, outcrossing rate, paternity analysis, selffertilization.

\section{Introduction}

In many self-compatible flowering plants, the spatial separation of male and female reproductive structures (herkogamy) varies considerably within and among populations (Ennos, 1981; Dole, 1992; Carr \& Fenster, 1994; Robertson et al., 1994; Barrett et al., 1996). Increased anther-stigma separation may reduce the amount of self-pollen deposited on the stigma, potentially increasing the proportion of ovules fertilized by outcross pollen (Ennos, 1981; Webb \& Lloyd, 1986; Lloyd \& Schoen, 1992). Several studies of species with mixed-mating systems have shown a positive correlation between population outcrossing rate and mean anther-stigma separation (Rick et al., 1977; Dole, 1991; Holtsford \& Ellstrand, 1992; Belaoussoff \& Shore, 1995). Despite considerable theoretical interest concerning the evolution of self-fertilization in natural populations (Holsinger, 1992; Jarne \& Charlesworth, 1993; Waller, 1993), much less is known about the relationship between herkogamy and outcrossing within populations. This relationship has recently been studied in experimental populations with discrete polymorphisms for anther-stigma separation (e.g. outcrossing rates of different morphs in populations of heterostylous species (Barrett \& Eckert, 1990;

*Correspondence. E-mail: karron@csd.uwm.edu
Kohn \& Barrett, 1994)). However, in most angiosperms, anther-stigma separation is a continuously distributed trait (Barrett \& Eckert, 1990; Carr \& Fenster, 1994; Fenster \& Ritland, 1994). Thus, there is a need for studies that examine the relationship between outcrossing rates and herkogamy of individuals within populations.

Outcrossing rates of individual genets have been difficult to quantify because (1) some of the assumptions of the mixed-mating model, especially uniform spatial distribution of pollen allele frequencies, may be violated (Brown, 1990; Morgan \& Barrett, 1990; Murawski \& Hamrick, 1992; Cruzan et al., 1994) and (2) standard errors for individual outcrossing rate estimates based upon the multilocus outcrossing estimation procedure (Ritland \& Jain, 1981; Ritland, 1990) tend to be fairly large (Ritland \& Ganders, 1985; Ritland, 1990; Boshier et al., 1995). Complete paternity analysis provides a more precise measure of individual outcrossing rates because every seed sampled from a maternal plant may be classified as either self or outcross (Brown et al., 1989; Karron et al., 1995a).

In this paper we test the hypothesis that outcrossing rates of Mimulus ringens (square-stemmed monkeyflower) genets will be positively correlated with anther-stigma separation. To facilitate paternity assignment for determining individual outcross- 
ing rates, we established replicate experimental populations consisting of genets with unique multilocus combinations of homozygous genotypes (Karron et al., 1995a,b; Karron, 1997).

\section{Materials and methods}

\section{Study organism}

Mimulus ringens L. (Scrophulariaceae) is a wetland perennial herb of central and eastern North America (Grant, 1924). Populations tend to be small, often with fewer than 50 individuals. Like many of its congeners (Sutherland \& Vickery, 1988; Ritland \& Ritland, 1989; Dole, 1992), M. ringens is self-compatible and has a mixed-mating system (Karron et al., 1995a). The showy blue hermaphroditic flowers last 1-2 days and are pollinated by worker and queen bumblebees (Bombus) (Karron $e t$ al., 1995a,b).

\section{Establishment of experimental arrays}

Seeds for breeding marker genotypes were harvested from a single diploid population in Kane County, Illinois. Anther-stigma separation varied widely among plants in this population $(\mathrm{CV}=68.9)$. By contrast, corolla length $(\mathrm{CV}=6.5)$ and corolla width $(\mathrm{CV}=10.8)$ showed much less variation.

The breeding programme for production of the marker genotypes is described in detail in Karron et al. (1995a); important features are as follows. Approximately 1500 seedlings from the Kane County population were genotyped at four unlinked allozyme loci: acid phosphatase (Acp-1, EC 3.1.3.2), aconitase (Aco-3, EC 4.2.1.3), glutamic-oxaloacetic transaminase (Got-1, EC 2.6.1.1), and shikimate dehydrogenase ( $S k d-1$, EC 1.1.1.25). Twenty-two (1.5 per cent) of the plants were heterozygous at all four loci and were cross-pollinated in a diallel design. Two thousand seeds harvested from the crosses were germinated and genotyped to identify 16 genets with unique multilocus combinations of homozygous genotypes.

Plants for two arrays were clonally propagated from the original set of marker genotypes to minimize differences in floral and vegetative morphology among populations. The arrays were planted in separate gardens at the UW-Milwaukee Field Station (Saukville, Wisconsin). Soil composition and drainage were uniform within and among these plots. The gardens were tilled before planting and mulched with hay to control weeds. The genets were planted in square arrays with a uniform spacing of $0.6 \mathrm{~m}$. There were four parallel rows, and four evenly spaced plants per row. Positions of clones in each population were randomly assigned. To minimize gene dispersal between arrays, the gardens were separated by $75 \mathrm{~m}$ of old field vegetation containing a high density of bumblebee-pollinated flowers. Long-distance gene flow from natural populations was unlikely because the nearest natural population was more than $15 \mathrm{~km}$ away.

\section{Measurement of anther-stigma separation}

In order to characterize thoroughly the herkogamy phenotype of each ramet, 10 flowers on every plant were randomly chosen for measurement. This sampling scheme ensured that flowers were sampled from several different positions along flowering stems. Each flower was measured with digital calipers to determine the minimum distance separating the stigma and closest anther. All measurements were taken on the first day a flower opened, between 09.00 and 11.00 hours.

\section{Determination of individual outcrossing rates}

In each population, 35 fruits were randomly harvested from every plant. This ensured that fruits were sampled from several different positions along fruiting stems. All seeds from a maternal family were pooled, and a random sample of 100 seeds was sown in a single pot. Germination rates exceeded 90 per cent. Two-week-old seedlings were transplanted individually into $5-\mathrm{cm}$ square cells in plastic flats. Sixty 6-week-old seedlings were randomly selected from each of the 32 maternal families, and these 1920 seedlings were genotyped at the four allozyme loci. Electrophoretic methods are described in Karron et al. (1995a). Because maternal plants were homozygous at each locus, all progeny resulting from selfing were also homozygous at these loci. By contrast, outcrossed progeny were heterozygous at one or more loci, and their paternity was assigned with a simple exclusion procedure (Ellstrand, 1984; Brown et al., 1989; Karron et al., 1995a).

\section{Data analyses}

After the onset of flowering, we observed very low levels of pollen production and reduced seed-set in three of the 16 clonal lines. This trait occurs in natural populations of $M$. ringens and is inherited as a single recessive gene (Karron et al., 1995a). In both populations these plants had outcrossing rates of 100 per cent. Because outcrossing rate in these genets is influenced by pollen sterility rather than by 
herkogamy, these three genets were excluded from the analyses.

Data on frequencies of self and outcross progeny for each maternal family were organized into contingency tables and tested with a homogeneity $\chi^{2}$ analysis (Steel \& Torrie, 1980; SAS Institute, 1990) to determine whether there were significant individual differences in outcrossing rate within populations.

Broad-sense heritabilities of anther-stigma separation and outcrossing rate were estimated as the within-genet correlation (Falconer, 1981). To test whether outcrossing rate was associated with herkogamy in each population, we calculated a Pearson's correlation coefficient for the outcrossing rate and mean anther-stigma separation of individuals in a population. To reduce the effects of position in the experimental arrays (e.g. number and identity of neighbours or unmeasured site-specific effects) on outcrossing rates, we also pooled data for each genet and calculated the correlation between the mean outcrossing rate of each genet and the mean antherstigma separation of each genet.

\section{Results}

Anther-stigma separation varied considerably among genets, ranging from $0.74 \pm 0.08 \mathrm{~mm}$ to $2.56 \pm 0.09 \mathrm{~mm}$ (Fig. 1; Table 1). This trait was highly consistent within genets and the estimate of broad-sense heritability was 0.88 (significance of the within-genet correlation was $P<0.001$, d.f. $=11$ ).

In population 1 , there was significant heterogeneity among maternal families in frequencies of selfing and outcrossing $\left(\chi_{12}^{2}=75.4, P<0.001\right.$ ) (Fig. 2 ). Outcrossing rates of individual plants ranged from 0.08 to 0.57 (Table 1). There was also significant among-family variation in frequencies of selfing

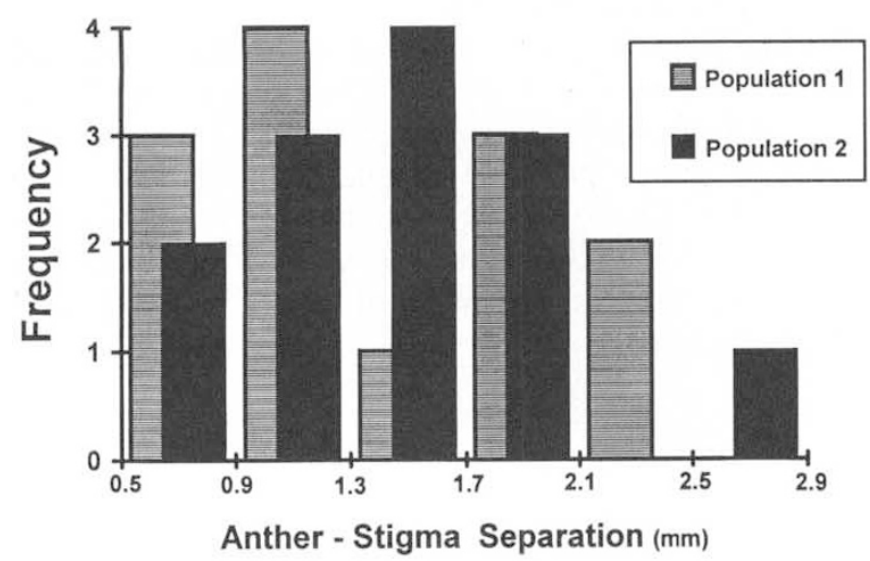

Fig. 1 The distribution of herkogamy phenotypes in two experimental populations of Mimulus ringens.

(C) The Genetical Society of Great Britain, Heredity, 79, 365-370.
Table 1 Means and coefficients of variation for two traits (herkogamy and outcrossing rate) in experimental populations of Mimulus ringens

\begin{tabular}{lccc}
\hline Trait & Population & Mean & CV \\
\hline Herkogamy (mm) & 1 & 1.42 & 40.01 \\
& 2 & 1.46 & 34.72 \\
Outcrossing rate & 1 & 0.34 & 45.51 \\
& 2 & 0.33 & 26.96 \\
\hline
\end{tabular}

and outcrossing in population $2 \quad\left(\chi_{12}^{2}=25.8\right.$, $P=0.01)$; individual outcrossing rates ranged from 0.18 to 0.48 (Fig. 2; Table 1). The estimate of broadsense heritability for outcrossing rate was 0.37 , but the within-genet correlation was not statistically significant $(P>0.2$, d.f. $=11)$.

The correlation between individual outcrossing rate and anther-stigma separation was significant in both populations (population $1, r=0.58, P<0.05$, d.f. $=11$; population $2, r=0.62, P<0.05$, d.f. $=11$ ). The mean outcrossing rate of each genet in the two populations was significantly correlated with the mean anther-stigma separation of each genet $(r=0.68, P<0.02$, d.f. $=11)($ Fig. 3)

\section{Discussion}

Our paternity data indicate that outcrossing rates of individual Mimulus ringens plants vary considerably within populations. Individual variation in outcrossing has been reported for several other species with mixed-mating systems, and has been attributed to a variety of factors, including: asynchrony in flowering times (Murawski \& Hamrick, 1992; Boshier et al., 1995); distance to nearest neighbours (Smyth \& Hamrick, 1984; Warwick \& Thompson, 1989);

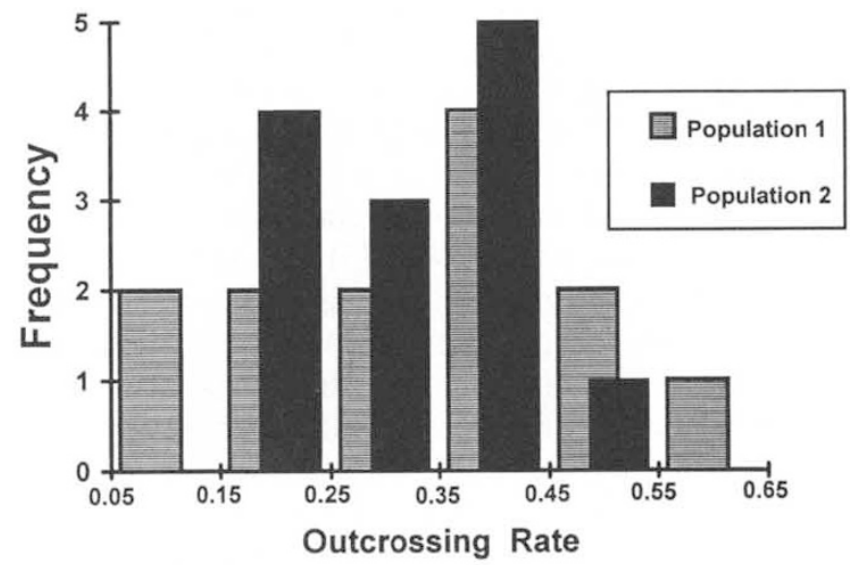

Fig. 2 The distribution of outcrossing rate phenotypes in two experimental populations of Mimulus ringens. 


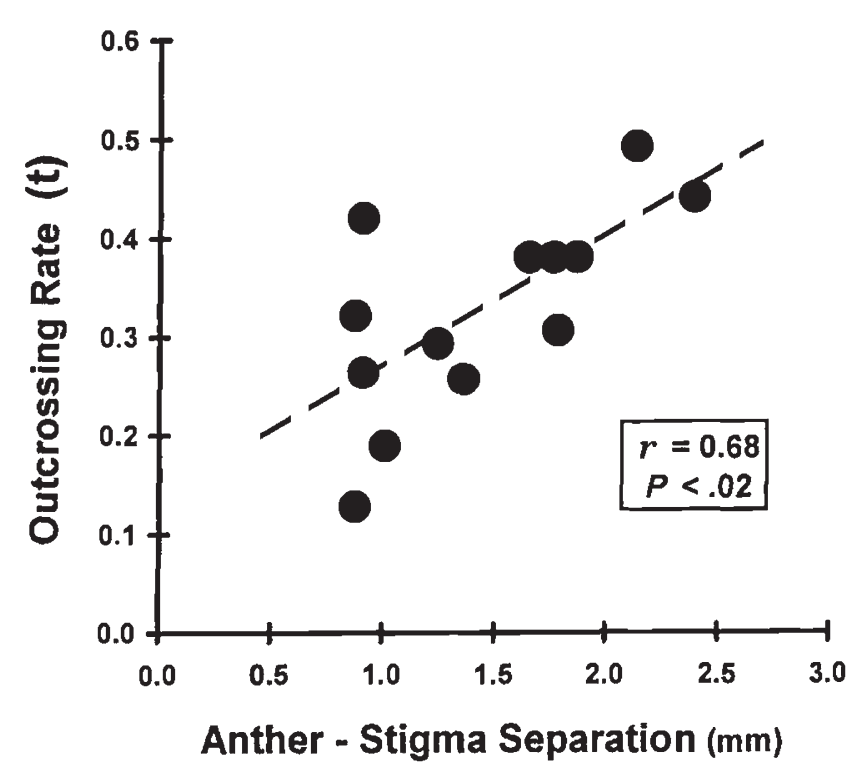

Fig. 3 The relationship between mean outcrossing rate and mean anther-stigma separation for 13 pollen-fertile genets of Mimulus ringens.

patterns of pollinator movement (Smyth \& Hamrick, 1984; Murawski \& Hamrick, 1992); aspects of floral morphology (Humphreys \& Gale, 1974; Epperson \& Clegg, 1987; Motten \& Antonovics, 1992; Damgaard \& Loeschcke, 1994); and genetic differences in levels of self-fertility (Warwick \& Thompson, 1989).

In this experiment, outcrossing rates of individual $M$. ringens genets were significantly correlated with anther-stigma separation. This result closely parallels the findings of previous studies that noted a positive relationship between population outcrossing rate and herkogamy. For example, Dole (1991) characterized floral morphology and outcrossing rate in eight subpopulations in a Mimulus guttatus $-M$. platycalyx hybrid zone. Outcrossing rate of subpopulations was strongly correlated $(r=0.94)$, with mean anther-stigma separation (calculated from data summarized in table 3 of Dole, 1991). Holtsford \& Ellstrand (1992) found a similar relationship in their study of seven populations of Clarkia tembloriensis; population outcrossing rate was strongly correlated $(r=0.85)$ with herkogamy.

In our experimental populations of Mimulus ringens, anther-stigma separation had a significant broad-sense heritability. This trait has also been shown to be heritable in glasshouse-grown populations of M. guttatus (Carr \& Fenster, 1994; Robertson et al., 1994). In both studies of $M$. guttatus, associations between herkogamy and autofertility were relatively weak. However, in contrast to our paternity analyses, glasshouse studies of autofertility do not detect facilitated selfing, which occurs when a pollinator transfers self-pollen within a flower (Dudash \& Ritland, 1991; Lloyd \& Schoen, 1992). This mode of selfing may be important in our populations of $M$. ringens, which lack the stigma closure mechanism characteristic of many populations in the Mimulus guttatus complex (Ritland \& Ritland, 1989).

The absence of a stigma closure mechanism may also explain why rates of selfing are higher in $M$. ringens than in large-flowered members of the $M$. guttatus complex (Ritland \& Ganders, 1987; Dole, 1991). In addition, plants of the highly clonal perennial $M$. ringens are often larger than $M$. guttatus, and frequently have 20 or more flowers open during a single day. Because pollinators often visit 4-12 flowers on a single $M$. ringens plant before flying on to another individual (Karron et al., 1995a), geitonogamous selfing may be more common in this species than in $M$. guttatus (LeClerc-Potvin \& Ritland, 1994).

In a previous paper (Karron et al., 1995a), we demonstrated that ecological and demographic factors, such as population density, can have a significant influence on outcrossing rates in Mimulus ringens. The results of the present study suggest that outcrossing rates are also influenced by genetically determined factors, such as anther-stigma separation. Future studies are needed to determine the relative contributions of genetic and environmental factors to variation in outcrossing rate phenotypes.

\section{Acknowledgements}

We thank Thomas Schuck for assistance with propagating Mimulus ringens. We are grateful to Amy Hessenauer for help in the laboratory, and to James Reinartz and Lou Nelson for building and maintaining the experimental research gardens at the UW-Milwaukee Field Station. David Carr, Jefferey Dole, Timothy Holtsford, James Reinartz and an anonymous reviewer provided helpful comments on the manuscript. This research was supported by United States National Science Foundation grant DEB-9119311 to J.D.K. and by a research award from the Graduate School of UW-Milwaukee. This is publication number 170 of the UW-Milwaukee Field Station.

\section{References}

BARRETT, S. C. H. AND ECKERT, C. G. 1990. Variation and evolution of mating systems in seed plants In: Kawano, S. (ed.) Biological Approaches and Evolutionary Trends in Plants, pp. 229-254. Academic Press, London. 
BARRETT, S. C. H., LLOYD, D. G. AND ARROYO, J. 1996. Stylar polymorphisms and the evolution of heterostyly in Narcissus (Amaryllidaceae). In: Lloyd, D. G. and Barrett, S. C. H (eds) Floral Biology: Studies on Floral Evolution in Animal-Pollinated Plants, pp. 339-376. Chapman \& Hall, London.

BELAOUSSOFF, S. AND SHORE, J. S. 1995. Floral correlates and fitness consequences of mating-system variation in Turnera ulmifolia. Evolution, 49, 545-556.

Boshier, D. H., ChaSe, M. R. AND BAWA, K. s. 1995. Population genetics of Cordia alliodora (Boraginaceae), a neotropical tree. 2. Mating system. Am. J. Bot., 82, 476-483.

BROWN, A. H. D. 1990. Genetic characterization of plant mating systems. In: Brown, A. H. D., Clegg, M. T., Kahler, A. L. and Weir, B. S. (eds) Plant Population Genetics, Breeding, and Genetic Resources, pp. 145-162. Sinauer, Sunderland, MA.

BROWN, A. H. D., BURDON, J. J. AND JAROSZ, A. M. 1989. Isozyme analysis of plant mating systems. In: Soltis, D. E. and Soltis, P. S. (eds) Isozymes in Plant Biology, pp. 73-86. Dioscorides Press, Portland, OR.

CARR, D. E. AND FENSTER, C. B. 1994. Levels of genetic variation and covariation for Mimulus (Scrophulariaceae) floral traits. Heredity, 72, 606-618.

CRUZAN, M. B., HAMR1CK, J. L., ARNOLD, M. L. AND BENNETT, B. D. 1994. Mating system variation in hybridizing irises: effects of phenology and floral densities on family outcrossing rates. Heredity, 72, 95-105.

DAMGAARD, C. AND LOESCHCKE, v. 1994. Genotypic variation for reproductive characters, and the influence of pollen-ovule ratio on selfing rate in rape seed (Brassica napus). J. Evol. Biol., 7, 599-607.

DOLE, J. A. 1991. Evolution of Mating Systems in the Mimulus guttatus Complex. Ph.D. Dissertation, University of California, Davis.

DOLE, J. A. 1992. Reproductive assurance mechanisms in three taxa of the Mimulus guttatus complex (Scrophulariaceae). Am. J. Bot., 79, 650-659.

DUDASH, M. R. AND RITLAND, K. 1991. Multiple paternity and self-fertilization in relation to floral age in Mimulus guttatus (Scrophulariaceae). Am. J. Bot., 78, 1746-1753.

ELLSTRAND, N. C. 1984. Multiple paternity within the fruits of the wild radish, Raphanus sativus. Am. Nat., 123, 819-828.

ENNOS, R. A. 1981. Quantitative studies of the mating system in two sympatric species of Ipomoea (Convolvulaceae). Genetica, 57, 93-98.

EPPERSON, B. K. AND CLEGG, M. T. 1987. First-pollination primacy and pollen selection in the morning glory, Ipomoea purpurea. Heredity, 58, 5-14.

FALCONER, D. S. 1981. Introduction to Quantitative Genetics, 2nd edn. Longman, New York.

FENSTER, C. B. AND RITLAND, K. 1994. Quantitative genetics of mating system divergence in the yellow monkeyflower species complex. Heredity, 73, 422-435.

GRANT, A. L. 1924. A monograph of the genus Mimulus. Ann. Mo. Bot. Gard., 11, 99-388.
HOLSINGER, K. E. 1992. Ecological models of plant mating systems and the evolutionary stability of mixed mating systems. In: Wyatt, R. E. (ed.) Ecology and Evolution of Plant Reproduction, pp. 169-191. Chapman \& Hall, London.

HOLTSFORD, T. P. AND EllSTRAND, N. C. 1992. Genetic and environmental variation in floral traits affecting outcrossing rate in Clarkia tembloriensis (Onagraceae). Evolution, 46, 216-225.

HUMPHREYS, M. O. AND GALE, J. S. 1974. Variation in wild populations of Papaver dubium. VII. The mating system. Heredity, 33, 33-42.

JARNE, P. AND CHARLESWORTH, D. 1993. The evolution of the selfing rate in functionally hermaphrodite plants and animals. Ann. Rev. Ecol. Syst., 24, 441-466.

KARRON, J. D. 1997. Genetic consequences of different patterns of distribution and abundance. In: Kunin, W. E. and Gaston, K. J. (eds) The Biology of Rarity, pp. 174-189. Chapman \& Hall, London.

KARRON, J. D., THUMSER, N. N., TUCKER, R. AND HESSENAUER, A. J. 1995a. The influence of population density on outcrossing rates in Mimulus ringens. Heredity, $\mathbf{7 5}$, $175-180$.

KARRON, J. D., TUCKER, R., THUMSER, N. N. AND REINARTZ, J. A. 1995b. Comparison of pollinator flight movements and gene dispersal patterns in Mimulus ringens. Heredity, 75, 612-617.

KOHN, J. R. AND BARRETT, S. C. H. 1994. Pollen discounting and the spread of a selfing variant in tristylous Eichhornia paniculata: evidence from experimental populations. Evolution, 48, 1576-1594.

LECLERC-POTVIN, C. AND RITLAND, K. 1994. Modes of selffertilization in Mimulus guttatus (Scrophulariaceae): a field experiment. Am. J. Bot., 81, 199-205.

LLOYD, D. G. AND SCHOEN, D. J. 1992. Self- and crossfertilization in plants. I. Functional dimensions. Int. J. Plant Sci., 153, 358-369.

MORGAN, M. T. AND BARRETT, S. C. H. 1990. Outcrossing rates and correlated mating within a population of Eichhornia paniculata (Pontederiaceae). Heredity, 64, 271-280.

MOTTEN, A. F. AND ANTONOVICS, J. 1992. Determinants of outcrossing rate in a predominantly self-fertilizing weed, Datura stramonium (Solanaceae). Am. J. Bot., 79, 419-427.

MURAWSKI, D. A. AND HAMRICK, J. L. 1992. Mating system and phenology of Ceiba pentandra (Bombacaceae) in Central Panama. J. Hered., 83, 401-404.

R1CK, C. M., FOBES, J. F. AND HOLLE, M. 1977. Genetic variation in Lycopersicon pimpinellifolium: Evidence of evolutionary change in mating systems. Pl. Syst. Evol., 127, 139-170.

RITLAND, C. AND RITLAND, K. 1989. Variation of sex allocation among eight taxa of the Mimulus guttatus species complex. Am. J. Bot, 76, 1731-1739.

RITLAND, K. 1990. A series of FORTRAN computer programs for estimating plant mating systems. J. Hered., 81, 235-237. 
RITLAND, K. AND GANDERS, F. R. 1985. Variation in the mating system of Bidens menziesii (Asteraceae) in relation to population substructure. Heredity, 55, 235-244.

RITLAND, K. AND GANDERS, F. R. 1987. Covariation of selfing rates with parental gene fixation within populations of Mimulus guttatus. Evolution, 41, 760-771.

RITLAND, K. AND JAIN, s. 1981. A model for the estimation of outcrossing rate and gene frequencies using $n$ independent loci. Heredity, 47, 35-52.

Robertson, A. w., DIAZ, A. AND MACNAIR, M. R. 1994. The quantitative genetics of floral characters in Mimulus guttatus. Heredity, 72, 300-311.

SAS InstituTE. 1990. SAS/STAT User's Guide, Version 6, 4th edn. SAS Institute, Cary, NC.

SMYTH, C. A. AND HAMRICK, J. L. 1984. Variation in estimates of outcrossing in musk thistle populations. $J$. Hered., 75, 303-307.
StEel, R. G. D. ANd TORRIE, J. H. 1980. Principles and Procedures of Statistics: a Biometrical Approach, 2nd edn. McGraw-Hill, New York.

SUTHERLAND, S. AND VICKERY, R. K. 1988. Trade-offs between sexual and asexual reproduction in the genus Mimulus. Oecologia, 76, 330-335.

WALlER, D. M. 1993. The statics and dynamics of mating system evolution. In: Thornhill, N. W. (ed.) The Natural History of Inbreeding and Outbreeding, pp. 97-117. University of Chicago Press, Chicago.

WARWICK, S. 1. AND THOMPSON, B. K. 1989. The mating system in sympatric populations of Carduus nutans, Carduus acanthoides and their hybrid swarms. Heredity, 63, 329-338.

WEBB, C. J. AND LloYD, D. G. 1986. The avoidance of interference between the presentation of pollen and stigmas in angiosperms. II. Herkogamy. N. Z. J. Bot., 24, 163-178. 